\title{
Changes in Haematological Parameters in Stroke Patients in Port Harcourt, Nigeria
}

\author{
Christian, Serekara Gideon ${ }^{1}$, Buseri, Fiekumo Igbida ${ }^{2}$, Eze, Evelyn Mgbeoma ${ }^{3}$ \\ 1, 2, ${ }^{3}$ Department of Medical Laboratory Science, Rivers State University of Science and Technology, \\ Nkpolu-Oroworukwo, Port Harcourt, Nigeria
}

\begin{abstract}
This was a case control study carried out on patients with stroke receiving medication at Braithwaite Memorial Specialist Hospital, Port Harcourt with the aim of identifying possible abnormal changes in haematological parameters associated with established stroke patients. The effect of stroke on haematological parameters was assessed and juxtaposed with apparently healthy control subjects without stroke. A total of 27 subjects diagnosed with stroke (15 females and 12 males) of age between 34 and 69; and 23 subjects (13 females and 10 males) that are apparently healthy of age between 30 and 62, enrolled as control, with all participants recruited between the first and second week of November, 2014. Haematological parameters were analysed using SYSMEX KX-21-N auto analyser. The results showed that there was statistically significant difference in the mean values of mean cell haemoglobin $26.91 \pm 2.44 \mathrm{pg}$ versus $33.77 \pm 0.98 \mathrm{pg}(p<0.0001)$, platelet count $205.80 \pm 58.30 \times 10^{9} / \mathrm{L}$ versus $257 \pm 64.15 \times 10^{9} / \mathrm{L}(p<0.05)$, and mean platelet volume $10.91 \pm$ $1.56 f l$ versus $9.85 \pm 1.23 \mathrm{fl}(p<0.05)$, other parameters showed no statistically significant difference. Comparing the changes observed in stroke based on gender, there was significant difference $(p<0.05)$ in mean platelet volume, red blood cell count, haemoglobin concentration, packed cell volume and white blood cell count; there was a significant increase in (mean platelet volume, red blood cells, haemoglobin concentration, packed cell volume and white blood cell count), other parameters showed no statistically significant difference. Based on duration of stroke, there was statistically significant difference $(p<0.05)$ in mean platelet volume, platelet distribution width, mean cell volume, and white blood cell count; those who had stroke for 5years and above showed significant increase in mean platelet volume and platelet distribution width and a significant decrease in mean cell volume. The high increase in mean platelet volume in stroke group can therefore be implicated as the major change in haematological parameters in stroke. Therefore, further studies are recommended on mean platelet volume.
\end{abstract}

Keywords: Stroke; Haematological parameters; Changes; Port Harcourt; Nigeria

\section{Introduction}

Stroke previously termed cerebrovascular accident, is a cerebrovascular event that results in a localized area of brain infarction (Starkweather and Banasik, 2010). Stroke occurs when there is a sudden interruption of blood flow to the brain, causing hypoxia in the process and, the effects includes paralysis of a limb or one side of the body and, disturbances in speech, and vision. The nature and extent of cerebral impairment depend on the size and location of affected blood vessels (Waugh and Grant, 2004).

When blood supply to a part of the brain is interrupted, insufficient blood supply to the brain damages or kills the cells in the area, and brings about the signs and symptoms of stroke. There are two general types of stroke: haemorrhagic and ischaemic stroke. Haemorrhagic stroke occurs when a cerebral artery or arteriole ruptures, sometimes but not always at the site of small aneurysm (Ganong, 2005). Haemorrhagic stroke accounts for about $12 \%$ of all stroke cases (Donnan et al., 2008) On the other hand, ischaemic stroke occurs when blood flow in a vessel is compromised by arteriosclerotic plagues and it eventually leads to thrombi formation (Ganong, 2005). Ischaemic stroke can also occur as a result of blockage of a blood vessel supplying blood to the brain consequent upon thrombosis, thromboembolism, cerebral hypoperfusion or atherosclerotic plague (Donnan et al., 2008).

The clinical features associated with stroke includes: hemiplegia/hemiparesis, cranial nerve deficit, headache, dizziness, altered level of consciousness, slurred speech, vomiting, blurring of vision and convulsion (Desalu et al.,
2011). Stroke can occur at any age, including childhood. However, the incidence of stroke increases exponentially from 30 years of age, and the aetiology varies by age (Elekjaer et al., 1997). It has been observed that stroke is more in elderly persons based on reports by National Institute of Neurological Disorders and Stroke (1995), and due to the complete or partial paralysis associated with stroke which they suffer these individuals gives more burdens to family members who do take care of them. The involvement of blood clot in stroke demands for effective and constant monitoring of haemostatic parameters in stroke patients in order to properly manage and treat them. Haemostasis is the process of forming clots in the walls of damaged blood vessels and preventing blood loss while also maintaining the blood in a fluid state within the vascular systems (Ganong, 2005), so it is necessary that blood continually be in a fluid form and free from clot to enable its smooth flow to the brain and thus prevent stroke.

This research work examined haematological parameters (that includes platelet count, mean platelet volume and platelet distribution with, which are test components of a full blood count), to ascertain any relationship with stroke. This study is to identify possible abnormal changes in haemostatic and haematological parameters associated with established stroke patients. The study also investigated the influence of stroke duration and gender on haematological parameters. According to this study, stroke had an impact on mean platelet volume which was high. 


\section{International Journal of Science and Research (IJSR) \\ ISSN (Online): 2319-7064 \\ Index Copernicus Value (2013): 6.14 | Impact Factor (2014): 5.611}

\section{Materials and Methods}

\subsection{Study Design}

This research work was a prospective study carried out on 27 subjects diagnosed with stroke (15 females and 12 males) of age between 34 and 69; and 23 subjects (13 females and 10 males) that are apparently healthy of age between 30 and 62 , enrolled as control. The patients were confirmed stroke patients who were receiving treatment from Braithwaite Memorial Specialist Hospital (BMSH), Port Harcourt. While the control subjects were apparently healthy individuals who were randomly recruited from Mile 4, Rumueme, Obio/Akpor Local Government Area. The bio-data and medical history of the subjects diagnosed with stroke were obtained from their folders.

\subsection{Sample Collection}

Venous blood sample was collected with the use of vacutainer from each participant, of which $3.0 \mathrm{ml}$ of the venous blood was collected into a glass bottle containing $0.5 \mathrm{ml}$ of $1.2 \mathrm{mg} / \mathrm{ml}$ dipotassium ethylene diamine tetra-acetic acid (EDTA) and was well mixed for full blood count. The samples were analysed within 2 hours after collection.

\subsection{Sample Analysis}

Samples for full blood count were analysed using an automated machine (SYSMEX manufactured by KOBE, Japan, model no: KX-21N).

\section{Principle}

The instrument performs blood cell count by direct current detection method. Blood sample is aspirated, measured to a predetermined volume, diluted at the specified ratio, and then fed into each transducer. The transducer chamber has a minute hole called the aperture. On both side of the aperture, there are electrodes between which flows direct current. Blood cells suspended in the diluted sample pass through the aperture, causing direct current resistance to change between the electrodes. As direct current resistance changes, the blood cell size is detected as electric pulses. Blood cell count is calculated by counting the pulses, and a histogram of blood cell sizes is plotted by determining the pulse sizes. Also analysing a histogram makes it possible to obtain various analysis data.

The full blood count parameters analysed included: red blood cell counts, white blood cell counts, packed cell volume, haemoglobin concentration, red cell indices (mean cell volume, mean cell haemoglobin and mean cell haemoglobin concentration), as well as, platelet count and platelet indices ( platelet distribution width and mean platelet volume).

\section{Results}

\subsection{Demographic details of participants}

A total of 50 individuals (27 individuals diagnosed with stroke, and 23 individuals that were apparently healthy, and without stroke), were recruited for the study. The age range for individuals with stroke was between 34years and 69years, while the age range of those used as control and without stroke was between 30years to 62years. For individuals with stroke, females were 15 while males were 12. Those without stroke were made up of 13 females and 10 males. Table 3.1 shows the demographic details of those recruited in the study.

Table 3.1: Demographic Details of Participants in the Study

\begin{tabular}{|c|c|c|}
\hline Parameters & Stroke Group $(\mathrm{n}=27)$ & Control Group $(\mathrm{n}=23)$ \\
\hline Number of females & 15 & 13 \\
\hline Number of males & 12 & 10 \\
\hline Age range (years) & $34-69$ & $30-62$ \\
\hline
\end{tabular}

\subsection{Haematological parameters in stroke patients}

Table 3.2 shows the comparison of the haematological parameters of the patients with stroke and those apparently healthy control subjects. There was no statistically significant difference in the mean values of red blood cell count $\left(4.57 \pm 0.63 \times 10^{12}\right.$ versus $\left.4.59 \pm 0.75 \times 10^{12}, \mathrm{p}>0.05\right)$, haemoglobin concentration $(12.18 \pm 1.41 \mathrm{~g} / \mathrm{dl}$ versus $12.56 \pm$ $1.86 \mathrm{~g} / \mathrm{dl}, \mathrm{p}>0.05)$, packed cell volume (PCV) (36.34 \pm $3.87 \%$ versus $34.88 \pm 4.93 \%$, $\mathrm{p}>0.05$ ), mean cell volume (MCV) $(80.39 \pm 4.35 f l$ versus $82.50 \pm 5.59 f l, p>0.05)$, mean cell haemoglobin concentration (MCHC) $(33.63 \pm 1.29 \mathrm{~g} / \mathrm{dl}$ versus $33.67 \pm 0.99 \mathrm{~g} / \mathrm{dl}, \mathrm{p}>0.05)$, total white blood cell count (TWBC) $\left(5.74 \pm 1.59 \times 10^{9} / \mathrm{L}\right.$ versus $5.08 \pm 0.78 \times$ $\left.10^{9} / \mathrm{L}, \mathrm{p}>0.05\right)$, and platelet distribution width (PDW) (15.16 $\pm 3.28 \mathrm{fl}$ versus $13.57 \pm 2.82 \mathrm{fl}, \mathrm{p}>0.05)$. Whereas there was statistically significant difference in the mean values of mean cell haemoglobin $(\mathrm{MCH}) 26.91 \pm 2.44 \mathrm{pg}$ versus 31.73 $\pm 3.35 \mathrm{pg}(\mathrm{p}<0.0001)$, platelet count $205.80 \pm 58.30 \times 10^{9} / \mathrm{L}$ versus $250 \pm 60.91 \times 10^{9} / \mathrm{L}(\mathrm{p}<0.05)$, and mean platelet volume $10.91 \pm 1.56 \mathrm{fl}$ versus $9.75 \pm 1.15 \mathrm{fl}(\mathrm{p}<0.05)$.

\subsection{Comparison of haematological and parameters in stroke patients based on gender}

Table 3.3 shows the comparison of haematological parameters made between males and females with stroke, using student t-test, there was significant difference ( $\mathrm{p} \leq$ 0.05 ) in some of the parameters analysed, which includes, mean platelet volume showed a p-value of 0.0279 and is considered to be statistically significant (females: $10.34 \pm$ $1.68 \mathrm{fl}$, males: $11.66 \pm 1.12 \mathrm{fl}$ ). On considering red blood cell count, packed cell volume and haemoglobin concentration (females: $4.21 \pm 0.42 \times 10^{12} / \mathrm{L}$, males: $5.09 \pm 0.53 \mathrm{X}$ $10^{12} / \mathrm{L}$ ), (females: $33.75 \pm 1.65 \%$, males: $39.58 \pm 3.37 \%$ ) and (females: $11.23 \pm 0.75 \mathrm{~g} / \mathrm{dl}$; males: $13.37 \pm 1.09 \mathrm{~g} / \mathrm{dl}$ ) in the same order, all had a p-value of $<0.0001$ which were highly significant. White blood cell counts (females: $4.85 \pm$ $0.47 \times 10^{9} / \mathrm{L}$, males: $6.87 \times 10^{9} / \mathrm{L}$ ) showed a statistically significant difference with p-value of 0.0003 . 


\section{International Journal of Science and Research (IJSR) ISSN (Online): 2319-7064 \\ Index Copernicus Value (2013): 6.14 | Impact Factor (2014): 5.611}

Table 3.2: Comparison of the mean haematological values of the study population

\begin{tabular}{|c|c|c|c|}
\hline $\begin{array}{c}\text { Parameters/ } \\
\text { Unit }\end{array}$ & $\begin{array}{c}\text { Stroke Group } \\
N=27\end{array}$ & $\begin{array}{c}\text { Control Group } \\
N=23\end{array}$ & p-value \\
\hline WBC $\left(\mathrm{X} 10^{9}\right)$ & $5.75 \pm 1.59$ & $5.08 \pm 0.78$ & 0.0745 (NS) \\
\hline Range & $4.00-9.00$ & $3.00-6.20$ & \\
\hline RBC $\left(\mathrm{X} 10^{12}\right)$ & $4.57 \pm 0.63$ & $4.59 \pm 0.75$ & 0.9196 (NS) \\
\hline Range & $3.60-6.10$ & $3.68-6.00$ & \\
\hline $\mathrm{Hb}(\mathrm{g} / \mathrm{dl})$ & $12.18 \pm 1.41$ & $12.56 \pm 1.86$ & 0.4113 (NS) \\
\hline Range & $10.20-14.60$ & $10.00-15.00$ & \\
\hline PCV (\%) & $36.34 \pm 3.87$ & $34.88 \pm 4.92$ & $0.2460(\mathrm{NS})$ \\
\hline Range & $29.90-44.30$ & $29.30-46.40$ & \\
\hline MCV (fl) & $80.39 \pm 4.35$ & $82.50 \pm 5.58$ & 0.1397 (NS) \\
\hline Range & $73.70-88.20$ & $72.80-91.70$ & \\
\hline MCH (pg) & $26.91 \pm 2.45$ & $31.73 \pm 3.35$ & $<0.0001(\mathrm{HS})$ \\
\hline Range & $23.30-31.40$ & $31.80-35.20$ & \\
\hline MCHC (g/dl) & $33.63 \pm 1.29$ & $33.67 \pm 0.99$ & 0.9045 (NS) \\
\hline Range & $31.30-35.70$ & $31.80-35.20$ & \\
\hline Platelet $\left(\mathrm{X} 10^{9}\right)$ & $205.80 \pm 58.30$ & $250.50 \pm 60.91$ & $0.0109(\mathrm{~S})$ \\
\hline Range & $122.00-308.00$ & $164.00-360.00$ & \\
\hline PDW (fl) & $15.16 \pm 3.28$ & $13.57 \pm 2.82$ & 0.0743 (NS) \\
\hline Range & $10.20-20.40$ & $10.10-20.80$ & \\
\hline MPV (fl) & $10.91 \pm 1.56$ & $9.75 \pm 1.15$ & $0.0050(\mathrm{~S})$ \\
\hline Range & $8.10-13.20$ & $8.20-11.60$ & \\
\hline
\end{tabular}

KEY: NS=Not Significant; HS=Highly Significant; $\mathrm{S}=$ Significant

\subsection{Comparison of haematological parameters based on duration of stroke}

On comparing the duration of the years the subjects have been suffering from stroke (table 3.4), there was statistical significance $(\mathrm{p} \leq 0.05)$ in four of the analyzed parameters: mean platelet volume (<5years: $10.34 \pm 1.74 \mathrm{fl}$, $\geq 5$ years: $11.73 \pm 0.87 \mathrm{fl}, \mathrm{p}=0.0203)$, platelet distribution width (<5years: $14.10 \pm 3.82 \mathrm{fl}, \geq 5$ years $16.71 \pm 1.32 \mathrm{fl}, \mathrm{p}=$ 0.0397), mean cell volume (<5years: $81.87 \pm 4.45 \mathrm{fl}$, $\geq$ 5years: $78.25 \pm 3.32 \mathrm{fl}, \mathrm{p}=0.0305)$, and white blood cell count (<5years: $5.24 \pm 1.51 \times 10^{9} / \mathrm{L}$, $\geq 5$ years: $6.48 \pm 1.47 \mathrm{X}$ $\left.10^{9} / \mathrm{L}, \mathrm{p}=0.0446\right)$. Other analysed parameters showed no statistically significant difference $(p>0.05)$ in mean values of $<5$ years duration when compared to mean values of $\geq 5$ years duration.

Table 3.3: Comparison of haematological parameters in patients with stroke based gender

\begin{tabular}{|c|c|c|c|}
\hline Parameters/Units & $\begin{array}{c}\text { Females } \\
\mathrm{N}=15\end{array}$ & $\begin{array}{c}\text { Males } \\
\mathrm{N}=12\end{array}$ & $\mathrm{p}$-value \\
\hline${\text { RBC }\left(\mathrm{X} 10^{12}\right)}^{12}$ & $4.21 \pm 0.42$ & $5.09 \pm 0.53$ & $<0.0001(\mathrm{HS})$ \\
Range & $3.60-5.14$ & $4.30-6.16$ & \\
\hline $\mathrm{Hb}(\mathrm{g} / \mathrm{dl})$ & $11.23 \pm 0.75$ & $13.37 \pm 1.09$ & $<0.0001(\mathrm{HS})$ \\
Range & $10.20-12.60$ & $10.90-14.60$ & \\
\hline PCV (\%) & $33.75 \pm 1.65$ & $39.58 \pm 3.37$ & $<0.0001(\mathrm{HS})$ \\
Range & $29.90-35.20$ & $34.90-44.30$ & \\
\hline MCV (fl) & $80.64 \pm 5.83$ & $80.08 \pm 1.18$ & $0.7482(\mathrm{NS})$ \\
Range & $73.70-88.20$ & $78.10-82.10$ & \\
\hline MCH (pg) & $26.85 \pm 3.13$ & $26.98 \pm 1.33$ & $0.8956(\mathrm{NS})$ \\
Range & $23.30-31.4$ & $24.40-28.60$ & \\
\hline MCHC (g/dl) & $33.23 \pm 1.57$ & $34.13 \pm 0.57$ & $0.0699(\mathrm{NS})$ \\
Range & $31.30-35.70$ & $33.30-34.90$ & \\
\hline WBC (X10 $\left.{ }^{9}\right)$ & $4.85 \pm 0.47$ & $6.87 \pm 1.80$ & $0.0003(\mathrm{HS})$ \\
Range & $4.00-5.50$ & $4.00-9.00$ & \\
\hline Platelets (X10 $\left.{ }^{9}\right)$ & $197.00 \pm 73.44$ & $215.80 \pm 31.22$ & $0.4374(\mathrm{NS})$ \\
Range & $122.00-308.00$ & $175.00-253.00$ & \\
\hline MPV (fl) & $10.34 \pm 1.68$ & $11.66 \pm 1.12$ & $0.0279(\mathrm{~S})$ \\
Range & $8.10-12.80$ & $9.90-13.20$ & \\
\hline
\end{tabular}

\begin{tabular}{|c|c|c|c|}
\hline $\begin{array}{c}\text { PDW (fl) } \\
\text { Range }\end{array}$ & $14.36 \pm 3.80$ & $16.17 \pm 2.25$ & 0.1591 (NS) \\
\hline
\end{tabular}

KEY: NS = Non Significant; HS = Highly Significant; S = Significant

Table 3.4: Comparison of haematological parameters of stroke patients based on duration of the stroke

\begin{tabular}{|c|c|c|c|}
\hline $\begin{array}{l}\text { Parameters/ } \\
\text { Units }\end{array}$ & $\begin{array}{c}<\text { 5years Duration } \\
N=16\end{array}$ & $\begin{array}{l}\text { zyyears Duration } \\
N=11\end{array}$ & p-value \\
\hline RBC $\left(X 10^{12}\right)$ & $4.49 \pm 0.69$ & $4.77 \pm 0.56$ & 0.2706 (NS) \\
\hline Range & $3.60-5.40$ & $4.23-6.16$ & \\
\hline $\mathrm{Hb}(\mathrm{g} / \mathrm{dl})$ & $11.97 \pm 1.43$ & $12.48 \pm 1.39$ & $0.3623(\mathrm{NS})$ \\
\hline Range & $10.20-14.40$ & $10.60-14.60$ & \\
\hline PCV (\%) & $36.27 \pm 4.66$ & $36.45 \pm 2.53$ & $0.9053(\mathrm{NS})$ \\
\hline Range & $29.90-44.30$ & $33.80-41.20$ & \\
\hline $\operatorname{MCV}(\mathrm{fl})$ & $81.87 \pm 4.45$ & $78.25 \pm 3.32$ & $0.0305(\mathrm{~S})$ \\
\hline Range & $76.80-88.20$ & $73.70-82.10$ & \\
\hline MCH (pg) & $27.39 \pm 2.49$ & $26.20 \pm 2.33$ & 0.2230 (NS) \\
\hline Range & $24.40-31.40$ & $23.30-28.60$ & \\
\hline MCHC (g/dl) & $33.77 \pm 4.66$ & $36.45 \pm 2.53$ & 0.9053 (NS) \\
\hline Range & $29.90-44.30$ & $33.8-41.20$ & \\
\hline WBC $\left(\mathrm{X} 10^{9}\right)$ & $5.24 \pm 1.51$ & $6.84 \pm 1.47$ & $0.0446(\mathrm{~S})$ \\
\hline Range & $4.00-8.30$ & $5.30-9.00$ & \\
\hline Platelets $\left(\mathrm{X} 10^{9}\right)$ & $206.10 \pm 72.61$ & $205.30 \pm 30.47$ & 0.9711 (NS) \\
\hline Range & $122.00-308.00$ & $175.00-253.00$ & \\
\hline MPV (fl) & $10.34 \pm 1.70$ & $11.73 \pm 0.87$ & $0.0203(\mathrm{~S})$ \\
\hline Range & $8.10-12.80$ & $10.60-13.20$ & \\
\hline PDW (fl) & $14.10 \pm 3.82$ & $16.71 \pm 1.32$ & $0.0397(\mathrm{~S})$ \\
\hline Range & $10.20-20.40$ & $14.70-18.10$ & \\
\hline
\end{tabular}

KEY: NS = Non Significant; S = Significant

\section{Discussion}

The results of this study revealed statistically a significant difference in mean platelet volume (stroke patients: $10.91 \pm$ 1.56fl; control group: $9.75 \pm 1.15 \mathrm{fl}$; $\mathrm{p}=0.005$ ), with stroke patients having a higher value than those in the control. Mean platelet volume when high may predispose an individual to having stroke (Dougherty et al., 1997), and so the value of mean platelet volume may be predictive of stroke. In this research, the stroke group showed higher value of mean platelet volume than the control group and there was a statistical significant difference after analysis of their data. This finding agrees totally with that of Shah et al., (2013) and Smith et al., (1999). There is statistically significant inverse relationship between platelet count and mean platelet volume in this study in comparison to the control group. This finding may be attributed to the constant consumption of platelets during the process of thrombosis.

Platelet count also showed a statistically significant difference (stroke patients: $205.8 \pm 58.3 \times 10^{9}$; control group: $250 \pm 60.91 \times 10^{9} ; \mathrm{p}=0.0109$ ), with control group having a significant higher mean value than stroke patients. This finding agrees with that of Smith et al., (1999) and Shah et al., (2013) where they observed similar differences in platelet counts but did not agree with the findings of Fujii et al., (2001), where they did not observed any significant difference in stroke group and normal individuals.

It was observed from this research that the stroke group have a higher platelet distribution width than the control group but there was no statistical significant difference. Shah et al., (2013), also observed a higher platelet distribution width in their study and so there is an agreement in this current study 


\section{International Journal of Science and Research (IJSR) \\ ISSN (Online): 2319-7064 \\ Index Copernicus Value (2013): 6.14 | Impact Factor (2014): 5.611}

with that of Shah and his colleagues on platelet distribution width in stroke.

In this study, it was observed that red blood cell count showed no significant difference between the stroke group and the control group. The values in both groups were within the normal range of individuals in the locality of study and this is in line with the findings of Shah et al., (2013) and Orefice et al., (2004).

There was no statistically significant difference in white blood cell count in stroke group and control group; the values of white blood cell count in both stroke and control group were within the normal range. This finding agrees with that of Fujii et al., (2001) and Orefice et al., (2004).

The haemoglobin levels in stroke group were within the normal range for individuals in the location of study, and there was no statistically significant difference in the values of those in the control group upon comparison. The findings agree totally with a recent study by Stanford et al., (2015) and that of Fujii et al., (2001). The normal levels of haemoglobin in stroke group observed may be as a result of the haematinics most of them have been taking; as the medication is usually included in their prescribed drugs.

There was no significant difference in packed cell volume in both studied groups. Their percentage packed cell volume was within the normal range of individuals that were apparently healthy. The statistically insignificant value of packed cell volume in this study agrees with that of Stanford et al., (2015).

For red cell indices, there was a statistical significant difference in mean cell haemoglobin ( $p<0.0001$ ), the control group having higher values of mean cell haemoglobin, but the values found in the stroke group which is lower than that of the control group is of no clinical implication because the values was within the normal range of healthy individuals and none of the subjects in the stroke group were found to be anaemic from the clinical diagnosis seen during their recruitment into the study. Other red cell indices (mean cell volume and mean cell haemoglobin concentration) showed no statistical significant difference in control group and stroke group. The values of the results in both groups were all within the normal range and this is because none of the subjects were anaemic.

On comparison of haematological parameters in males and females, there were significant differences in mean platelet volume, red blood cell count, haemoglobin concentration, packed cell volume and white blood cell count. The significant differences in haematological parameters in males and females were as a result of the normal differences observed in the reference ranges in these parameters for healthy population.

On comparing the difference in duration of stroke, there was statistically significant differences in some parameters (mean cell volume, platelet distribution width, mean cell volume, and white blood cell count). There was no statistically significant difference in other parameters that were studied in this research. The parameters that showed statistical difference had values that were within the range of values of those recruited as control subjects.

\section{Conclusion}

High mean platelet volume has been implicated as a predisposing factor for individuals who have stroke (Dougherty et al., 1997), and since mean platelet volume was high in stroke group than in control group, it can be said that that individuals with high mean platelet volume are at risk of having stroke. Therefore, further studies are recommended on mean platelet volume.

\section{References}

[1] Starkweather, A. R. \& Banasik, J. L. (2010). Acute Disorders of Brain Function. In: Copstead, L. C. \& Banasik, J. L. (Eds). Pathophysiology, $4^{\text {th }}$ edition. St Louis, Missouri. Saunders Elservier.

[2] Waugh, A. \& Grant, A. (2004). Anatomy and Physiology in Health and Illness. 9th Edition, Philadelphia, Churchill Livingstone.

[3] Ganong, W. F. (2005). Review of Medical Physiology. $22^{\text {nd }}$ Edition, USA, McGraw Hill.

[4] Donnan, G. A., Fisher, M., Macleod, M. \& Davis, S. M. (2008). Stroke. Lancet, 371(9624), 1612-1623.

[5] Desalu, O. O., Wahab, K. W., Fawale, B., Olarenwaju, T. O., Busari1, O. A., Adebowale O. Adekoya, A. O. \& Oluwafemi Afolayan, J. O. (2011). A review of stroke admissions at a tertiary hospital in rural Southwestern Nigeria. Annals of African Medicine, 10(2), 79-85.

[6] Elekjaer, H., Holmen, J., Indredavik, B. \& Terent, A. (1997). "Epidemiology of Stroke in Innherred, Norway, 1994 to 1996: Incidence and 30-Day Case-Fatality Rate". Stroke, 28 (11), 2180-2184.

[7] National Institute of Neurological Disorders and Stroke (NINDS). (1995) Stroke Study Group. Tissue plasminogen activator for acute ischemic stroke. New England of Journal Medicine, 333, 1581.

[8] Dougherty, J. H., Levy, D. E. \& Weksler B. B. (1997). Platelet activation in acute cerebral ischaemia. Lancet, 1, $821-824$

[9] Shah, P. A., Mir, R. A., Kamdi, M. M. A., Bardi, G. H. \& Masordi, Z. A. (2013). Role of Mean Platelet Volume in Ischaemic Stroke. JK Science, 15(1), 136-139.

[10] Smith, N. M., Pathansali, R. \& Bath, P. M. W. (1999). Platelet and Stroke. Vascular Medicine, 4, 165 - 172.

[11] Fujii, Y., Takeuchi, S., Harada, A., Abe, H., Osamu, S. \& Tanaka, R. (2001). Haemostatic Activation in Spontaneous Intracerebral Haemorrhage. Stroke, 32, 883-890.

[12] Orefice, G., Grasso, A., Fazio, N., Vecchio, G. D., Volpe, G., Coppola, M., D’Allessio, A. \& Carrieri, P.B. (1994). No Effect of Cloricromen on some Coagulation Parameters in Patients with Ischaemic Cerebrovascular Disease. The Journal of International Medical Research, 22, 287-291.

[13] Stanford, S. N., Sabra, A., D'Silva, L., Lawrence, M., Morris, R. H. K., Storton, S., Brown, M. R., Evans, V., Hawkins, K., Williams, P. R., Davidson, S. J., Wani, M., Potter, J. F. \& Evans, P. A. (2015). The Changes in Clot Microstructure in Patients with Ischaemic Stroke and the effect of Therapeutic Intervention: a Prospective Observational Study. BioMedCentral Neurology, 15, 35. 